\title{
Utilization of Saudi Wheat Straw in the Production of Protein-rich Biomass
}

\author{
Wadiah Saleh Backer \\ Biochemistry Department, (Girl section), Faculty of Science, \\ King Abdulaziz University, Jeddah, Saudi Arabia
}

\begin{abstract}
Wheat straw, a raw material abundantly available in the Kingdom of Saudi Arabia was obtained from western province of the Kingdom and was thoroughly ground to powder form. Trichoderma viride was selected as experimental organism to produce protein-rich biomass. Hydrolyzed ground wheat straw gave the highest proteinrich biomass. The potent nitrogen source was found $\mathrm{NH}_{4} \mathrm{NO}_{3}$ at concentration of $5 \mathrm{mg} / \mathrm{ml}$ compared to other sources. The microbial biomasses obtained was found to be rich in several biochemical constituents which allowed to be used as animal fodder with cheap cost.
\end{abstract}

Keywords: Wheat straw, Microbial biomass, Trichoderma viride, Animal fodder.

\section{Introduction}

Wheat straw (WS), a lignocellulosic material contains cellulose, hemicellulose and lignin, is the major production crop in Saudi Arabia. The rate of production has been estimated over 2.5 million ton per year $^{[1,2]}$. The $\alpha$-cellulose content of wheat straw is an excellent raw material for industrial production that it can be easily hydrolyzed into glucose which is utilized by microorganisms to produce animal fodder ${ }^{[3]}$. Wheat straw is comparatively much cheaper substrate, was used instead of costly substrate (pure cellulose or lactose) to produce complete cellulse system. A pan bioreactor was developed for solid-state fermentation (SSF) to yield highly of complete cellulase system compared to that in the liquid-state fermentation (LSF) from WS, when 
treated with $4.25 \% \mathrm{NaOH}$ at $121^{\circ} \mathrm{C}$ for $1 \mathrm{~h}$. and mixed with Mandel's medium $^{[4]}$. A complete cellulase system is defined as one in which the ratio of $\beta$-glucosidase activity to filter paper activity (FPA) in the enzyme solution is close to 1.0. Mandel (1974) investigations on the mutant of Trichoderma viride led to strain QM 9136 which yielded more than 80\% glucose using wheat straw as substrate ${ }^{[5]}$. Another mutant strain of $T$. reesei MCG 80 proved to be best by producing an optimal cellulase system with wheat straw as substrate. The preparation exhibited a $\beta$ glucosidase activity to filter paper activity (FPA) ratio of about 1.0 which indicate a high potential for hydrolysis of cellulose ${ }^{[6]}$. Gaspar et al. (1997), reported that wheat straw is also the best substrate to produce xylanase complex which is a cellulase free and have an optimal activity at $\mathrm{pH}$ 4.6-5.0 and $55-60^{\circ} \mathrm{C}$ on birchwood xylane ${ }^{[7]}$. The components of WS can be hydrolyzed (except lignin) to produce sugars which can then be fermented to produce fuel ethanol. Numerous studies have been published in the last two decades indicating the importance role of wheat straw as raw material for several industrial products ${ }^{[8-13]}$. The purpose of the present investigation is to address the utilization of wheat straw which is abundantly available in Saudi Arabia and usually wasted to produce a protein-rich biomass to be used as an animal fodder.

\section{Materials and Methods}

\section{Collection of Wheat Straw}

Wheat straw was obtained from western province of the Kingdom of Saudi Arabia. It was cut into small pieces and dried in an oven at $90^{\circ} \mathrm{C}$. The dry wheat straw were thoroughly ground to powder form to use in further experiments. All chemicals and solvents used in this study were of the purest analytical grade. They were purchased from different local chemical agents available in the market.

\section{Maintenance Medium}

The medium contained the following ingredients (g/l): glucose, 10.0; peptone, 2.5; yeast extract 2.5; $\mathrm{KH}_{2} \mathrm{PO}_{4}, 1.0 ; \mathrm{MgSO}_{4} .7 \mathrm{H}_{2} \mathrm{O}, 0.25$; $\mathrm{MnSO}_{4} .4 \mathrm{H}_{2} \mathrm{O}, 0.02 ; \mathrm{FeSO}_{4} .7 \mathrm{H}_{2} \mathrm{O}, 0.005$; agar, 30.0 in 1000 distilled water. The ingredients were mixed thoroughly and the initial $\mathrm{pH}$ was adjusted to 6.0. The medium was poured into test tubes containing $10 \mathrm{ml}$ and plugged with cotton and sterilized at $121^{\circ} \mathrm{C}$ for $15 \mathrm{~min}$. The slants were inoculated with experimental organisms under aseptic conditions, 
and incubated at $30{ }^{\circ} \mathrm{C}$ for $72 \mathrm{~h}$ to obtain luxuriant growth. The organisms were maintained on a slant and stored at $5^{\circ} \mathrm{C}$.

\section{Vegetative Medium}

The medium contained the following ingredients $(\mathrm{g} / \mathrm{l})$ : glucose, 10.0; peptone, 5.0; yeast extract 5.0; $\mathrm{KH}_{2} \mathrm{PO}_{4}, 1.0 ; \mathrm{MgSO}_{4} .7 \mathrm{H}_{2} \mathrm{O}, 0.25$; $\mathrm{MnSO}_{4} .4 \mathrm{H}_{2} \mathrm{O}, 0.025 ; \mathrm{FeSO}_{4} .7 \mathrm{H}_{2} \mathrm{O}, 0.005$; in 1000 distilled water. The initial $\mathrm{pH}$ was adjusted to 6.50 . Fifty milliliters of the medium was portioned in $250 \mathrm{ml}$ Erlenmeyer flasks which cotton plugged and sterilized at $121^{\circ} \mathrm{C}$ for $20 \mathrm{~min}$. When the flasks attained room temperature, they were inoculated with $2 \mathrm{ml}$ of the vegetative medium contained organisms. The flasks were shaken $(200 \mathrm{rpm})$ at $30^{\circ} \mathrm{C}$ for 168 $\mathrm{h}$. At the end of the fermentation process, the following parameters were determined, the final $\mathrm{pH}$ values, reducing sugars liberated, total biomass and total protein present in biomass.

\section{Experimental Organism}

The fermentation medium prepared above was inoculated with two experimental organisms, Trichoderma viride NRRL 13680 and cellulomonas fimi NRRL B-403. Five Erlenmeyer flasks were used for each organism. The flasks were shaken $(200 \mathrm{rpm})$ at $30^{\circ} \mathrm{C}$ for $T$. viride and at $37^{\circ} \mathrm{C}$ for $C$. fimi for $168 \mathrm{~h}$. At the end of the fermentation process, the final $\mathrm{pH}$ values, reducing sugars liberated, biomass and total protein in biomass were determined.

\section{Hydrolyzed Ground Wheat Straw as Carbon Source}

Two fermentation media were prepared, one contained hydrolyzed and the other non-hydrolyzed ground wheat straw. The media were inoculated with $T$. viride and flasks were shaken $(200 \mathrm{rpm})$ at $30^{\circ} \mathrm{C}$ for $168 \mathrm{~h}$. The above parameters were determined.

\section{Determination of the Optimum Concentration of Hydrolyzed Wheat Straw}

Five different concentrations of hydrolyzed wheat straw $(10,20,30$, 40 and $50 \mathrm{~g} / \mathrm{l})$ were incorporated in fermentation medium to obtain the optimum concentration. At the end of fermentation process the previous mentioned parameters were determined. 


\section{Nitrogen Sources}

Ammonium sulphate in concentration of $4.0 \mathrm{~g} / \mathrm{l}$ of fermentation medium was substituted by an equivalent amount of different nitrogen sources included, $\mathrm{NH}_{4} \mathrm{Cl} ; \mathrm{KNO}_{3}, \mathrm{NaNO}_{3}$ and $\mathrm{NaNO}_{2}$. The fermentation process was carried out as before and the previous parameters were determined.

\section{Determination of Biomass}

Cell biomasses of $T$. viride NRRL 13680 were determined at the end of fermentation process. The fermented media was centrifuged at 4000 rpm for 2 min to precipitate the microbial cells of $T$. viride, then, dried at $95^{\circ} \mathrm{C}$ till constant weight was obtained ${ }^{[14]}$.

\section{Determination of Sugars Liberated in the Medium}

Sugars were determined according to the colorimetric method of Somogyi ${ }^{[15]}$. A standard curve was constructed using different concentrations of glucose.

\section{Determination of Protein Concentration}

The most widely used method for determining protein concentration is Lowry method which was used to determine protein concentration ${ }^{[16]}$.

\section{Results and Discussion}

The results presented in Table 1 showed that the microorganism Trichoderma viride NRRL 13680 was selected for further studies on the basis of the results obtained in Table 1 which indicates that the organism $T$. viride produced higher percentage of protein (24.40) compared to the other organism Cellulomonas fimi.

Table 2 showed that the hydrolyzed ground wheat straw as carbon source produced higher protein percentage than unhydrolyzed. When different concentrations of ground wheat straw was used to obtain the optimum concentration as carbon source, the organism $T$. viride produced $30.9 \mathrm{mg} / \mathrm{ml}$ of dry cell biomass at $50 \mathrm{mg} / \mathrm{ml}$ of ground wheat straw beside the concentration of reduced sugar is the higher at the same concentration (Table 3). The results presented in Table 4 showed that $\mathrm{NH}_{4} \mathrm{NO}_{3}$ is more suitable than urea and $\left(\mathrm{NH}_{4}\right)_{2} \mathrm{SO}_{4}$ as nitrogen source for the growth of $T$. viride, and the optimum concentration was $5.0 \mathrm{mg} / \mathrm{ml}$ on the basis of percentage of protein $37.5 \%$ (Table 5). The final $\mathrm{pH}$ values 
for fermented media in each experiment was mainly shifted to be the more acidic side due to the formation of some acidic metabolites namely organic and inorganic acids during the fermentation process. The production of protein-rich biomass by fermentation of wheat straw as carbon source by utilizing organisms decomposing cellulase such as $T$. viride allows agricultural wastes to be utilized economically to produce protein-rich animal fodder from local renewable material and in very cheap cost.

Table 1. Cultivation of Trichoderma viride NRRL 13680 and Cellulomonas fimi NRRL B403 on ground wheat straw as carbon source.

\begin{tabular}{|l|c|c|}
\hline \multicolumn{1}{|c|}{ Organism } & $\begin{array}{c}\text { Trichoderma viride } \text { NRRL } \\
\mathbf{1 3 6 8 0}\end{array}$ & $\begin{array}{c}\text { Cellulomonas fimi NRRL } \\
\text { B-403 }\end{array}$ \\
\hline Final $\mathrm{pH}$ value* & 3.7 & 3.8 \\
Sugar $(\mathrm{mg} / \mathrm{ml})$ & 0.14 & 1.05 \\
Biomass $(\mathrm{mg} / \mathrm{mg})$ & 30.0 & 32.0 \\
Total protein $(\mathrm{mg} / \mathrm{ml})^{* *}$ & 0.244 & 0.22 \\
\% Proteins & 24.400 & 22.00 \\
\hline
\end{tabular}

* The initial $\mathrm{pH}$ value of fermentation medium was 6.5.

$* *(\mathrm{mg} / \mathrm{mg})=(\mathrm{mg}$ proteins $/ \mathrm{mg}$ dry biomass $)$.

Table 2. Cultivation of Trichoderma viride NRRL 13680 on hydrolyzed and unhydrolyzed ground wheat straw as carbon source.

\begin{tabular}{|l|c|c|}
\hline \multicolumn{1}{|c|}{ Organism } & \multicolumn{2}{c|}{ Trichoderma viride NRRL 13680 } \\
\hline \multicolumn{1}{|c|}{ Wheat straw } & Hydrolyzed & Unhydrolyzed \\
\hline Final $\mathrm{pH}$ value* & 5.3 & 5.5 \\
Sugar $(\mathrm{mg} / \mathrm{ml})$ & 0.5 & 0.4 \\
Biomass $(\mathrm{mg} / \mathrm{mg})$ & 37.0 & 32.5 \\
Total protein $(\mathrm{mg} / \mathrm{ml}) * *$ & 0.325 & 0.255 \\
\% Proteins & 32.500 & 25.500 \\
\hline
\end{tabular}

* The initial $\mathrm{pH}$ value of fermentation medium was 6.5.

** $(\mathrm{mg} / \mathrm{mg})=(\mathrm{mg}$ proteins $/ \mathrm{mg}$ dry biomass $)$.

The results findings of this study agreed with numerous studies of investigation in the utilization of wheat straw as a good raw material for production of several cheap and economical products. Nabawia et al. (1983) found that ensiling straw, treated or untreated, caused a clear improvement in its nutritive value ${ }^{[17]}$. Dahot and Noomrio (1996) utilized wheat straw as a carbon and energy source for the growth of Aspergillus 
fumigatus and production of cellulase ${ }^{[18]}$. The high content of cellulose $(34 \%)$ in wheat straw makes it suitable as raw material for production of bioethanol as fuel instead of petrol which makes the net contribution to the green house effect zero ${ }^{[19]}$. Pure vision technology (2004) has produced clean fiber from biomass and agricultural waste materials by converting wheat straw into usable pulp and paper ${ }^{[20]}$. Wheat straw and barley straw was used for cattle, sheep, goats fattening after treatment with urea ${ }^{[21]}$.

Table 3. Cultivation of Trichoderma viride NRRL 13680 on different hydrolyzed ground wheat straw concentrations as carbon source.

\begin{tabular}{|c|c|c|c|c|c|}
\hline $\begin{array}{c}\text { Hydrolyzed } \\
\text { ground wheat } \\
\text { straw (mg/ml) }\end{array}$ & $\begin{array}{c}\text { Final pH } \\
\text { value* }\end{array}$ & $\begin{array}{c}\text { Reducing } \\
\text { sugars (mg/ml) }\end{array}$ & $\begin{array}{c}\text { Dry } \\
\text { biomass } \\
(\mathbf{m g} / \mathbf{m l})\end{array}$ & $\begin{array}{c}\text { Total } \\
\text { Proteins } \\
(\mathbf{m g} / \mathbf{m g} * *)\end{array}$ & $\begin{array}{c}\% \\
\text { Proteins }\end{array}$ \\
\hline 0.0 & 6.4 & 0.0 & 0.0 & 0.0 & 0.0 \\
10 & 4.9 & 0.50 & 5.6 & 0.297 & 29.7 \\
20 & 5.2 & 0.60 & 10.7 & 0.303 & 30.3 \\
30 & 5.5 & 0.65 & 18.5 & 0.314 & 31.3 \\
40 & 5.4 & 0.60 & 27.0 & 0.300 & 30.0 \\
50 & 5.4 & 0.70 & 30.9 & 0.254 & 25.4 \\
\hline
\end{tabular}

* The initial $\mathrm{pH}$ value of fermentation medium was 6.5.

** $(\mathrm{mg} / \mathrm{mg})=(\mathrm{mg}$ proteins $/ \mathrm{mg}$ dry biomass $)$.

Table 4. Cultivation of Trichoderma viride NRRL 13680 on different nitrogen sources on using hydrolyzed ground wheat straw as carbon source.

\begin{tabular}{|c|c|c|c|c|c|}
\hline $\begin{array}{c}\text { Nitrogen } \\
\text { source* }\end{array}$ & $\begin{array}{c}\text { Final pH } \\
\text { value** }\end{array}$ & $\begin{array}{c}\text { Reducing } \\
\text { sugars } \\
\mathbf{( m g / m l}\end{array}$ & $\begin{array}{c}\text { Dry } \\
\text { biomass } \\
(\mathbf{m g} / \mathbf{m l})\end{array}$ & $\begin{array}{c}\text { Total } \\
\text { Proteins } \\
(\mathbf{m g} / \mathbf{m g} * * *)\end{array}$ & $\begin{array}{c}\% \\
\text { Proteins }\end{array}$ \\
\hline$\left(\mathrm{NH}_{4}\right)_{2} \mathrm{SO}_{4}$ & 4.5 & 0.20 & 18.3 & 0.335 & 33.0 \\
$\mathrm{NH}_{4} \mathrm{NO}_{3}$ & 4.2 & 0.22 & 21.5 & 0.354 & 35.4 \\
$\mathrm{NH}_{4} \mathrm{CL}$ & 4.1 & 0.10 & 19.5 & 0.314 & 31.4 \\
$\mathrm{NaNO}_{3}$ & 7.1 & 0.17 & 18.5 & 0.292 & 29.2 \\
$\mathrm{KNO}_{3}$ & 7.4 & 0.21 & 19.4 & 0.285 & 28.5 \\
$\mathrm{NaNO}_{2}$ & 8.7 & 0.17 & 18.7 & 0.291 & 29.1 \\
$\mathrm{Ura}^{*}$ & 8.7 & 1.9 & 21.3 & 0.344 & 34.4 \\
\hline
\end{tabular}

* Equivalent amounts of nitrogen sources were added to the fermentation medium.

**The initial $\mathrm{pH}$ value of fermentation medium was 6.5 .

$* * *(\mathrm{mg} / \mathrm{mg})=(\mathrm{mg}$ proteins $/ \mathrm{mg}$ dry biomass $)$. 
Table 5. Cultivation of Trichoderma viride NRRL 13680 on different $\mathrm{NH}_{4} \mathrm{NO}_{3}$ concentrations on using hydrolyzed ground wheat straw as carbon source.

\begin{tabular}{|c|c|c|c|c|c|}
\hline $\begin{array}{c}\mathbf{N H}_{\mathbf{4}} \mathbf{N O}_{\mathbf{3}} \\
(\mathbf{m g} / \mathbf{m l})\end{array}$ & $\begin{array}{c}\text { Final } \mathbf{~ p H} \\
\text { value* }^{*}\end{array}$ & $\begin{array}{c}\text { Reducing } \\
\text { sugars } \\
(\mathbf{m g} / \mathbf{m l})\end{array}$ & $\begin{array}{c}\text { Dry } \\
\text { biomass** } \\
(\mathbf{m g} / \mathbf{m l})\end{array}$ & $\begin{array}{c}\text { Total } \\
\text { Proteins } \\
\left(\mathbf{m g} / \mathbf{m g} \mathbf{m}^{* * *}\right)\end{array}$ & $\begin{array}{c}\mathbf{\%} \\
\text { Proteins }\end{array}$ \\
\hline 0.0 & 6.4 & 0.0 & 0.0 & 0.0 & 0.0 \\
1.0 & 5.5 & 0.12 & 23.3 & 0.124 & 12.4 \\
2.0 & 5.2 & 0.15 & 21.7 & 0.215 & 21.5 \\
3.0 & 4.9 & 0.20 & 20.8 & 0.203 & 30.5 \\
4.0 & 4.3 & 0.23 & 18.5 & 0.350 & 35.0 \\
5.0 & 4.7 & 0.24 & 17.5 & 0.375 & 37.5 \\
6.0 & 4.5 & 0.23 & 18.4 & 0.370 & 37.5 \\
7.0 & 4.5 & 0.24 & 18.2 & 0.360 & 36.5 \\
\hline
\end{tabular}

* The initial $\mathrm{pH}$ value of fermentation medium was 6.5 .

** Dry biomass $=$ Residual wheat straw + microbial biomass.

$* * *(\mathrm{mg} / \mathrm{mg})=(\mathrm{mg}$ proteins $/ \mathrm{mg}$ dry biomass $)$.

\section{References}

[1] Ministry of Agriculture and Water, Statistical Indicator for Agriculture and Water in Saudi Arabia, Department of Economic Studies and Statistics, Saudi Arabia (1988a).

[2] Ministry of Agriculture and Water, Agrucultural Sector Development, Graphical Indicators, Department of Economic Studies and Statistics, Saudi Arabia (1988b).

[3] Abou-Zeid, A.A. and El-Diwany, A.I., Cellulose decomposing fungi, Zbl. Bakt. II. Abt. Bd. 3II: 647-656 (1978).

[4] Chahal, P.S., Chahal, D.S. and Le, G.B., Production of cellulase in solid-state fermentation with Trichoderma reesei MCG 80 on wheat straw, J. Applied Biochem. and Biotech., 57-58: 433-442 (1996).

[5] Mandels, M., Hontz, L. and Nystrom J., Enzymatic hydrolysis of cellulose. Biotech. Bioeng., 16: 1471-1479 (1974).

[6] Awafo, V.A., Chahal, D.S., Simpson, B.K. and Le, GB., Production of cellulase system by selected mutants of Trichoderma reesei in solid-state fermentation and their hydrolytic potentials, J. Applied Biochem. and Biotech. 57-58: 461-470 (1996).

[7] Gospar, A., Cosson, T., Roques, C. and Thonart, P., Study on the production of a xylanolytic complex from Penicillium Canescens 10-10c., J. Applied Biochem. and Biotech., 67(1-2): 45-58 (1997).

[8] Kahlon, S.S. and Kalra, K.L., Biological upgradation of wheat straw into protein-rich feed, J. of Research, Punjab Agri Univ., 26(2): 257-65 (1989).

[9] Kumar, N. and Singh, K., Chemical and microbiological changes during solid substrate fermentation of wheat straw with coprinus fimetarius, Biological wastes, 33(4): 231-242 (1990).

[10] Iniguez, C.G, Torre, M.M., De La Cuaron-Ibal-guengoitia, J.A., Perez, G.P., Magana, P. and De La Torro-Martinez, Fermentation characteristics of swine waste ensiled with wheat straw and cane molasses, Biological wastes, 34(3): 227-239 (1987).

[11] Bachmann, S.L. and McCarthy, A.J., Purification and cooperative activity of enzymes constituting the xylane-degrading system of Thermomonospora fusca. Appl. and Environ. Micro., 57(8): 2121-2130 (1991). 
[12] Houdeou, G., Olivier, J.M., Libmond, S. and Bawadikji, H., Improvement of pleurotus cultivation, Mushroom Science, Mahel, M. J. Dublin, Irish Republic, XIII Vol. 2ed.: 549-554 (1991).

[13] Teunissen, M.J., Kort, G.V.M. de. and Capm, H.J.M., Production of cellulolytic and xylanolytic enzymes during growth of the anoerobic fungus piromyces $s p$. on different substrates, J. of Gen. Microbio., 138(8): 1657-1664 (1992).

[14] Official Methods of Analysis of Association of Official Analytical Chemists (1975).

[15] Somogyi, M., A new reagent for the determination of sugars, J. Biol. Chem., 160: 61 (1945).

[16] Lowry, O.H., Rosebrough, N.J., Farr, A.L. and Randall, R.J., Protein measurement with the folin phenol reagent, J. Biol. Chem., 193(1): 265-75 (1951).

[17] Nabawia, E., Abaza, M.A., El-Shazly, N. and Naga, M., The nutritive value of ensiled alkali treated straw for fattening rams, Second African workshop on utilization of low quality roughages with special reference to developing countries, University of Alexandria, Egypt (1983).

[18] Dahot, Umar M. and Hanif Noomrio, M., Microbiol production of cellulases by Aspergillus fumigatus using wheat straw as a carbon source, J. of Islamic Academy of Science, 9(4): 201-209 (1996).

[19] Jakosson, Eva-Lena, Optimization of the pretreatment of wheat straw for production of bioethanol, (1996), http://www.google.com/search, access date Dec. 2004.

[20] Pure vision technology, Wheat straw to purified cellulose fiber utilizing novel reactive fractionation process, (2004), http://www.purevisiontechnology.com. access date Dec. 2004.

[21] Celik, K., Ersoy, I.E. and Savran, F., Feeding of urea treated wheat straw in Saanen Goat male kids, Pakistan J. of Nutrition, 2(4): 258-261(2003). 


\section{الاستفادة من فش القمح السعودي في إنتاج البروثين غني الكتلة الحيوبة}

\section{وديعة بنت صالح بكّر}

قسم الكبياء الحيوية، كلية العلوم، جامعة الملك عبدالعزيز

المستخلص. أخذ بعض فش القمح و المنوفر بكميــات كبيــرة فـــي

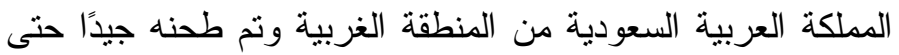

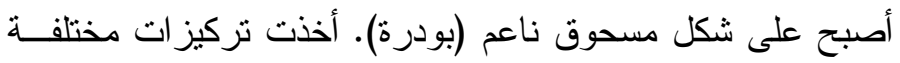

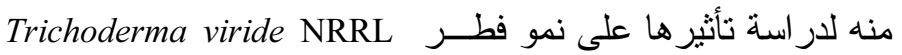

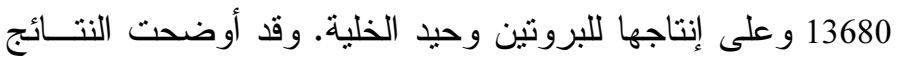

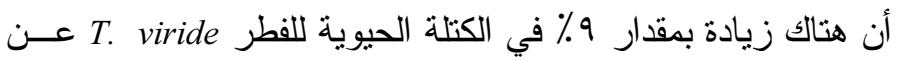
بكتيريا Cellulomonas fimi NRRL B-403 و على ذلك تم اســـتخدام

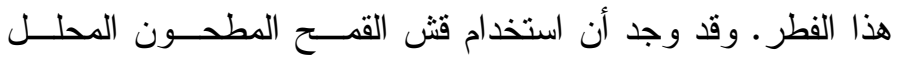

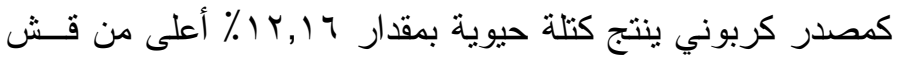

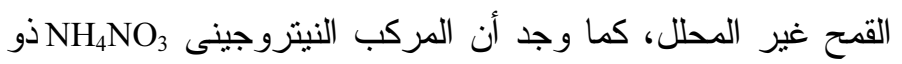
تركيز ه جم/مل هو أفضل مصدر نبتروجيني للبكتريا من المصادر النيتزووجينية الأخرى. - مئ.

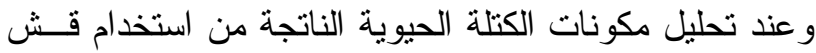
القمح المطحون المحلل الذي أدى إلى زيادة ملحوظة في نمو الفطر

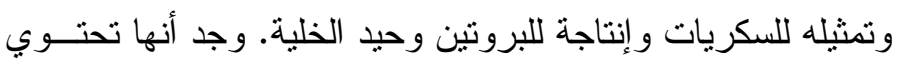

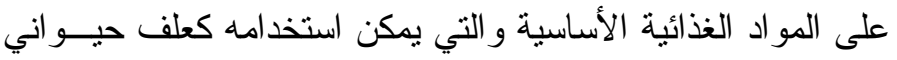
ذو تكلفة مادية قليلة جدًا مقارنةً بأعلاف الأغذية الأخرى. 